\title{
Nickel-based perovskite catalysts: synthesis and catalytic tests in the production of syngas
}

\section{(Catalisadores à base de níquel com estrutura perovskita: síntese e testes catalíticos na produção de gás de síntese)}

\author{
E. O. Moraes Júnior ${ }^{1}$, J. O. Leite ${ }^{1}$, A. G. Santos ${ }^{1}$, M. J. B. Souza ${ }^{2}$, A. M. Garrido Pedrosa ${ }^{1 *}$ \\ ${ }^{1}$ Federal University of Sergipe, Department of Chemistry, Av. Mal. Rondon, s/n, 49100-000, \\ S. Cristóvão, SE, Brazil \\ ${ }^{2}$ Federal University of Sergipe, Department of Chemical Engineering, S. Cristóvão, SE, Brazil
}

\begin{abstract}
$\mathrm{La}_{1-\mathrm{x}} \mathrm{Sr}_{x} \mathrm{NiO}_{3}(\mathrm{x}=0.0,0.3$ or 0.7$)$ perovskite-type oxides were synthesized using the modified proteic gel method and using collagen as an organic precursor. Catalysts of $\mathrm{La}_{1-x} \mathrm{Sr}_{x} \mathrm{NiO}_{3} / \mathrm{Al}_{2} \mathrm{O}_{3}$ were obtained using the wet impregnation method. The synthesized catalysts were characterized by X-ray diffraction, surface area and temperature-programmed reduction. The catalysts were evaluated in the partial oxidation reaction of methane, and the levels of selectivity to $\mathrm{CO}, \mathrm{CO}_{2}, \mathrm{H}_{2}$ and $\mathrm{H}_{2} \mathrm{O}$ were determined. Among the catalysts studied, the catalyst $\mathrm{LaNiO} / \mathrm{Al}_{2} \mathrm{O}_{3}$ had the highest methane conversion level (78\%) and higher $\mathrm{H}_{2}$ selectivity (55\%).
\end{abstract}

Keywords: $\mathrm{La}_{1-\mathrm{x}} \mathrm{Sr}_{x} \mathrm{NiO}_{3}$, perovskite-type oxides, modified proteic gel method, partial oxidation of methane.

Resumo

Perovskitas do tipo $\mathrm{La}_{1-x} \mathrm{Sr}_{x} \mathrm{NiO}_{3}(x=0,0,0,3$ ou 0,7) foram sintetizadas utilizando o método do gel proteico modificado e usando colágeno como precursor orgânico. Catalisadores do tipo $\mathrm{La}_{1-x} \mathrm{Sr}_{x} \mathrm{NiO}_{3} / \mathrm{Al}_{2} \mathrm{O}_{3}$ foram obtidos utilizando-se o método da impregnação úmida. Os catalisadores sintetizados foram caracterizados por difratometria de raios $X$, área superficial e redução à temperatura programada. Os catalisadores foram avaliados na reação de oxidação parcial do metano, e os níveis de seletividade ao $\mathrm{CO}, \mathrm{CO}_{2}, \mathrm{H}_{2}$ e $\mathrm{H}_{2} \mathrm{O}$ foram determinados. Dentre os catalisadores estudados, o catalisador $\mathrm{LaNiO}_{3} / \mathrm{Al}_{2} \mathrm{O}_{3}$ foi o que apresentou maior nivel de conversão de metano (78\%) e maior seletividade ao $\mathrm{H}_{2}(55 \%)$.

Palavras-chave: $\mathrm{La}_{1-x} \mathrm{Sr}_{x} \mathrm{NiO}_{3}$, óxidos do tipo perovskita, método do gel proteico modificado, oxidação parcial do metano.

\section{INTRODUCTION}

Many of the studied catalysts for applications in chemical industry processes are based on mixed metal oxides. The specific preparation of these oxides, which are capable of performing complex functions, is one of the main research topics in the field of heterogeneous catalysis [1]. Among the mixed metal oxides, those with a perovskite structure constitute a family of crystalline ceramic materials of the $\mathrm{ABO}_{3}$-type formula, which have recently been recognized as active catalysts, replacing noble metals [1,2]. In these oxides, A is a large cation, such as alkali metals, alkaline earths and rare earths and B is a small cation, such as a transition metal. In general, they have well defined structures, the perovskite being ideal cubic type. However, these structures

*annemgp@ufs.br often appear distorted, especially for the orthorhombic and rhombohedral symmetries [3]. It is possible to carry out partial substitutions of cations A and B without changing the fundamental structure of the perovskite [4]. The effect of the partial replacement of the cation A, usually by a rare earth metal, and especially with elements with oxidation state other than +3 , has been frequently studied [5-7]. However, interest in perovskite studies is promising in applications involving high temperatures due to their high stability. These materials have been considered important due to their electronic, optical, catalytic properties, among others [8].

The perovskites may present some structural defects, which can occur through the doping of the sites in the crystalline structure, generating excess or vacancy of oxygen [9]. In some cases, doping with $\mathrm{Sr}$ at A-site can generate non-stoichiometric perovskites with excess oxygen and cation vacancies [10]. Thus, the influence on the amount of $\mathrm{Sr}$ may influence the formation of the spinel structure, 
$\mathrm{La}_{2} \mathrm{NiO}_{4}$, which, like the perovskite structure, presents high thermal and mechanical stability $[10,11]$. In addition, it offers resistance to wear related to the reaction conditions and is widely used in the study of solid-oxide fuel cell (SOFC) $[10,12]$. In general, the perovskite properties are influenced by the synthesis method, calcination conditions (temperature, time and atmosphere) and substitutions at sites A and/or B. There are now several methods of obtaining ceramics oxides with perovskite type structure, such as the conventional powder technology, the Pechini method, the chelating precursor method, the proteic sol-gel method and the combustion synthesis process, among others [13-15].

Some researchers have used synthetic routes similar to the polymer precursor method in which gelatin replaces ethylene glycol as a polymerization agent to obtain nanoparticles. This method consists in forming a complex metal chelate, including a chelating agent and a precursor metal, replacing ethylene glycol and citric acid or EDTA with gelatin. The method is distinguished by its simplicity and ability to obtain crystalline materials with high purity and good stoichiometric control. It is an alternative route to obtain oxides with high efficiency and low cost [16]. Researchers showed that it is possible to obtain perovskites through the collagen-modified proteic gel method with formation of a single-phase material at $700{ }^{\circ} \mathrm{C}[6,16]$. In this work, oxides of $\mathrm{La}_{1-x} \mathrm{Sr}_{x} \mathrm{NiO}_{3}(\mathrm{x}=0.0,0.3$ or 0.7 ) type were synthesized using the modified proteic gel method using collagen as an organic precursor. This method was chosen because it is reported as a low cost and relatively simple route to obtain some materials, which results in the production of pure materials with good stoichiometric control. Materials supported on alumina of $\mathrm{La}_{1-\mathrm{x}} \mathrm{Sr}_{\mathrm{x}} \mathrm{NiO}_{3} /$ $\mathrm{Al}_{2} \mathrm{O}_{3}(\mathrm{x}=0.0,0.3$ or 0.7$)$ type were also synthesized by the impregnation method. The activity of the catalysts was evaluated in the partial oxidation of methane and promising results are presented.

\section{MATERIALS AND METHODS}

Synthesis of perovskites: $\mathrm{La}_{1-\mathrm{x}} \mathrm{Sr}_{\mathrm{x}} \mathrm{NiO}_{3}(\mathrm{x}=0.0,0.3$ or $0.7)$ perovskite-type oxides were performed by the collagenmodified proteic gel method using nickel (Vetec, 97\%), lanthanum (Vetec, 99.9\%) and strontium (Synth, 99\%) nitrates as the starting material and collagen (Santosflora, 95\%) as chelating agent. The synthesis procedure consisted of the dissolution of the nickel(II) nitrate in distilled water under magnetic stirring at $30^{\circ} \mathrm{C}$ for $30 \mathrm{~min}$. Then, the solid lanthanum(III) nitrate was added to the system and kept under stirring for $30 \mathrm{~min}$. For substituted oxides, lanthanum nitrate was added together with the strontium(II) nitrate in the molar ratios of 0.3 and 0.7 . After this time, the solution was heated to $70{ }^{\circ} \mathrm{C}$, and then the chelating agent was added. After addition of the collagen, the temperature was maintained at $70{ }^{\circ} \mathrm{C}$ for $1.5 \mathrm{~h}$ resulting in a viscous gel which was heat treated at $350{ }^{\circ} \mathrm{C}$ for $2 \mathrm{~h}$ at a heating rate of $10{ }^{\circ} \mathrm{C} \cdot \mathrm{min}^{-1}$, resulting in a precursor powder which was calcined at $900{ }^{\circ} \mathrm{C}$ for $2 \mathrm{~h}$ using a $10^{\circ} \mathrm{C} \cdot \mathrm{min}^{-1}$ heating ramp.
The samples treated at $350{ }^{\circ} \mathrm{C}$ were named $\mathrm{LN}-3$ for $\mathrm{LaNiO}_{3}$, L7S3N-3 for the sample $\mathrm{La}_{0.7} \mathrm{Sr}_{0.3} \mathrm{NiO}_{3}$, and L3S7N-3 for the sample $\mathrm{La}_{0.3} \mathrm{Sr}_{0.7} \mathrm{NiO}_{3}$. The calcined samples at $900{ }^{\circ} \mathrm{C}$ were named $\mathrm{LN}$ for $\mathrm{LaNiO}_{3}, \mathrm{~L} 7 \mathrm{~S} 3 \mathrm{~N}$ for the sample $\mathrm{La}_{0.7} \mathrm{Sr}_{0.3} \mathrm{NiO}_{3}$, and $\mathrm{L} 3 \mathrm{~S} 7 \mathrm{~N}$ for the sample $\mathrm{La}_{03} \mathrm{Sr}_{07} \mathrm{NiO}_{3}$. The calcined catalysts were supported on alumina (Merck, 99\%) using the solvent impregnation method [16] starting with an ethanolic suspension of the perovskites. After the impregnation procedure, the samples were subjected to drying at $60{ }^{\circ} \mathrm{C}$ for $1 \mathrm{~h}$. The supported catalysts were synthesized aiming to obtain $15 \%$ of the perovskite base in the support and were named LNA $\left(\mathrm{LaNiO}_{3} / \mathrm{Al}_{2} \mathrm{O}_{3}\right)$, L7S3NA $\left(\mathrm{La}_{0.7} \mathrm{Sr}_{0.3} \mathrm{NiO}_{3} /\right.$ $\mathrm{Al}_{2} \mathrm{O}_{3}$ ), and $\mathrm{L} 3 \mathrm{~S} 7 \mathrm{NA}\left(\mathrm{La}_{0.3} \mathrm{Sr}_{0.7} \mathrm{NiO}_{3} / \mathrm{Al}_{2} \mathrm{O}_{3}\right)$.

Characterization of perovskites: the thermogravimetric analyzes of the synthesized materials were carried out in a Shimadzu, TGA-50, in a nitrogen atmosphere, with a flow of $40 \mathrm{~mL} \cdot \mathrm{min}^{-1}$, at a heating rate of $10{ }^{\circ} \mathrm{C} \cdot \mathrm{min}^{-1}$, in the temperature range from 30 to $900{ }^{\circ} \mathrm{C}$ using about $5 \mathrm{mg}$ of sample. The Fourier transform infrared spectroscopy (FTIR) of the samples were recorded in the range of 4000 to $400 \mathrm{~cm}^{-1}$ in a Varian, 640-IR, spectrophotometer, using the $\mathrm{KBr}$ pellet method. The X-ray diffractograms were obtained using a Rigaku, DMAX100, diffractometer, operated with $\mathrm{CuK} \alpha$ and $2 \theta$ in the range of 10 to $60^{\circ}$, at a velocity of $2^{\circ} \cdot \mathrm{min}^{-1}$, and step of $0.02^{\circ}$. Phase identification was performed by comparison with data from JCPDS (Joint Committee on Powder Diffraction Standards). The surface area of the catalysts was determined by $\mathrm{N}_{2}$ physisorption at $77 \mathrm{~K}$ with the Quantachrome, Nova 1200, equipment. Temperature-programmed reduction (TPR) was performed using about $100 \mathrm{mg}$ of sample in a Micromeritics, AutoChem II 2920, equipment. The reducing atmosphere of the reactor consisted of a mixture of $10.1 \% \mathrm{H}_{2}$ in $\mathrm{N}_{2}$, with a flow of $50 \mathrm{~mL} \cdot \mathrm{min}^{-1}$. The system was heated from 50 to $1000{ }^{\circ} \mathrm{C}$ using a heating rate of $10{ }^{\circ} \mathrm{C} \cdot \mathrm{min}^{-1}$. A thermal conductivity detector was used to analyze the gas after water scraping. The catalytic tests were performed in a Micromeritics, Autochem II, reactor coupled to a Hiden, HPR20, mass spectrometer. The mass of catalyst used was $100 \mathrm{mg}$, and the reaction temperature was $900{ }^{\circ} \mathrm{C}$ under inert gas flow (He). The reactor containing the catalyst was subjected to 8 OSC (oxygen storage capacity) cycles with the combinations of 20 pulses of hydrogen and 10 pulses of oxygen as reducing and oxidizing, respectively. After the OSC cycles, two reaction cycles were programmed, each containing 15 pulses of methane as reducing agent and 15 pulses of oxygen as oxidizing agent. All pulses were monitored by the mass spectrometer. In order to quantify the components involved in the CSO and reaction processes, previous calibrations of the pure gas system were made as standard, simulating the same operating conditions and using quartz $\left(\mathrm{SiO}_{2}\right)$ as an inert solid in the reactor.

\section{RESULTS AND DISCUSSION}

The thermogravimetric curves of the thermally treated precursor powders at $350{ }^{\circ} \mathrm{C}$ are shown in Fig. 1. The 
precursor powder decomposition steps occurred at similar temperature ranges for all samples $(\mathrm{LN}-3, \mathrm{~L} 3 \mathrm{~S} 7 \mathrm{~N}-3$ and L7S3N-3). It was possible to observe that the decomposition steps, in general, occurred in three or four temperature ranges. In the first temperature range, from 30 to $350^{\circ} \mathrm{C}$, a mass loss occurred due to the release of water remaining of the synthesis process, and due to the initial decomposition of the remaining organic material. The largest percentage of mass loss observed for the LN-3 sample in comparison with other samples was due to this sample possibly having a greater amount of water remaining. In the second temperature range, from 350 to $580{ }^{\circ} \mathrm{C}$, for the $\mathrm{LN}-3$ and $\mathrm{L} 7 \mathrm{~S} 3 \mathrm{~N}-3$ samples the mass loss was related to the decomposition of the carboxylates, with subsequent formation of carbonates, which were decomposed in the temperature range between 580 and $800{ }^{\circ} \mathrm{C}$. On the other hand, the sample L3S7N-3 showed a different decomposition profile of the carboxylates and carbonates in relation to the profile of the other samples. Furthermore, these decompositions occurred in the other temperature range. It is possible to observe that even at $900{ }^{\circ} \mathrm{C}$, the sample still show a mass loss, which can be attributed to the decomposition of carbonates formed [17]. It was possible to observe a slight mass gain above 670 and $830^{\circ} \mathrm{C}$ in the samples LN-3 and L7S3N-3, respectively, due to the oxidation reactions, as observed in other studies for perovskite of nickel-based synthesis [16, 17].

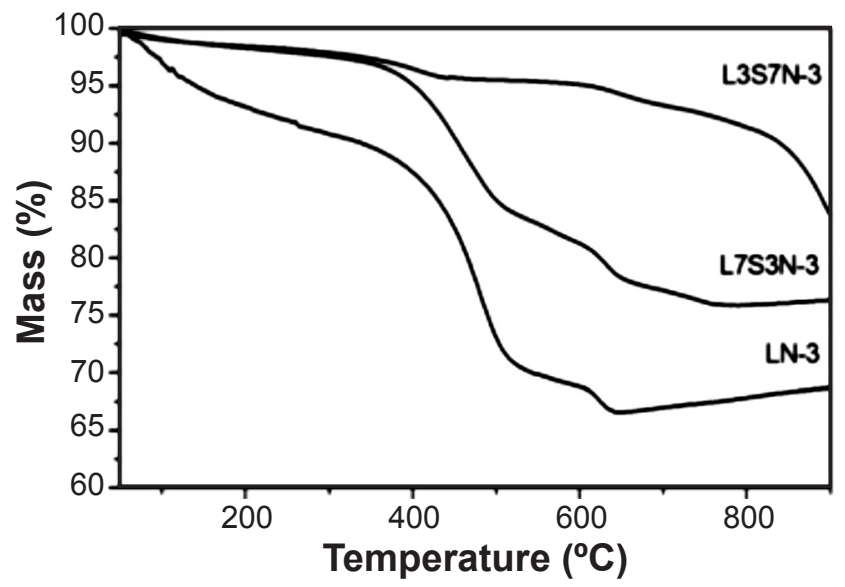

Figure 1: Thermogravimetric curves of the thermally treated precursor powders at $350{ }^{\circ} \mathrm{C}(\mathrm{LN}-3, \mathrm{~L} 3 \mathrm{~S} 7 \mathrm{~N}-3$ and $\mathrm{L} 7 \mathrm{~S} 3 \mathrm{~N}-3)$.

[Figura 1: Curvas termogravimétricas dos pós precursores tratados termicamente a $350{ }^{\circ} \mathrm{C}(L N-3, L 3 S 7 N-3$ e L7S $3 N-3)$.]

Fig. 2 shows the absorption spectra in the infrared region of samples heat treated at $350{ }^{\circ} \mathrm{C}$ for $2 \mathrm{~h}$. All absorption spectra presented wide bands in the region between 3670$3280 \mathrm{~cm}^{-1}$, which can be attributed to the stretching vibrations of the remaining $\mathrm{O}-\mathrm{H}$ group of the synthesis $[18,19]$. In the region of $1500-1340 \mathrm{~cm}^{-1}$, bands were observed that can be attributed to the metal coordination by the carboxylate and amine groups of the collagen, since these vibrations are displaced when compared with the collagen spectrum bands (1637-1380 $\left.\mathrm{cm}^{-1}\right)$. However, the characteristic bands between $1000-400 \mathrm{~cm}^{-1}$ are related to the possible coordination of the carboxylate groups of the collagen with lanthanum, nickel or strontium [20]. The spectra of the heattreated samples at $900{ }^{\circ} \mathrm{C}$ (result not shown) indicated the disappearance of the bands characteristic of the carboxylate groups and the amines present in the collagen. The samples L7S3N and L3S7N showed bands at 1455 and $857 \mathrm{~cm}^{-1}$ which may be associated with the formation of strontium carbonate, being more intense in the sample L3S7N due to the higher concentration of strontium present in this sample $[21,22]$.

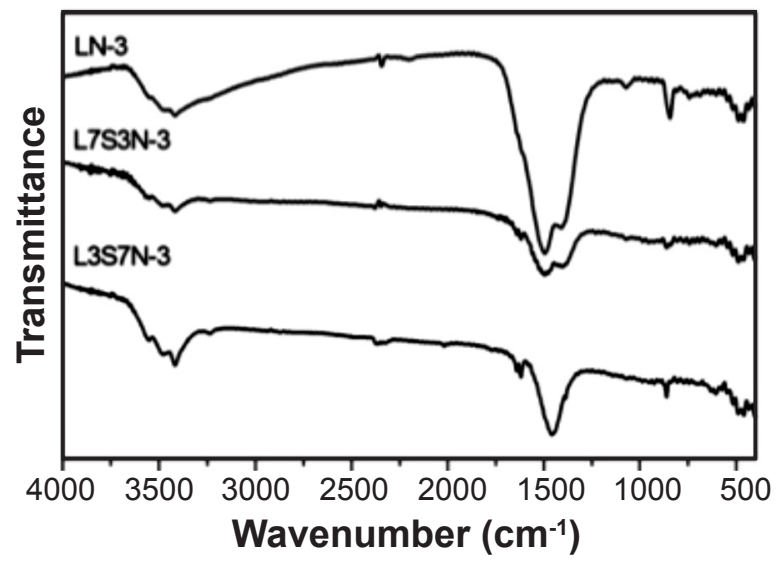

Figure 2: Absorption spectra in the infrared region of the thermally treated precursor powders at $350{ }^{\circ} \mathrm{C}(\mathrm{LN}-3, \mathrm{~L} 3 \mathrm{~S} 7 \mathrm{~N}-3$ and L7S3N-3).

[Figura 2: Espectros de absorção na região do infravermelho dos pós precursores tratados termicamente a $350{ }^{\circ} \mathrm{C}(L N-3, L 3 S 7 N-3$ e $L 7 S 3 N-3)$.]

The X-ray diffraction patterns of the catalysts $\mathrm{La}_{1-\mathrm{x}} \mathrm{Sr}_{x} \mathrm{NiO}_{3}(\mathrm{x}=0.0,0.3$ or 0.7$)$ are shown in Fig. 3. All samples showed the formation of the perovskite crystalline phase, according to the diffraction pattern of the lanthanum nickel structure, obtained in the literature (JCPDS). The perovskite phase was identified by the peaks of higher intensities in $2 \theta$ of $32.7^{\circ}, 40.7^{\circ}, 47.2^{\circ}, 53.5^{\circ}$ and $58.6^{\circ}$ that are in accordance with the file JCPDS 330711, related to the presence of perovskite $\mathrm{LaNiO}_{3}$, with rhombohedral structure and group space $R-3 m$. In the case of the strontium-substituted samples, besides the $\mathrm{LaNiO}_{3}$ phase, there were secondary phases related to nickel oxide $(\mathrm{NiO})$, strontium oxide $(\mathrm{SrO})$, and strontium carbonate $\left(\mathrm{SrCO}_{3}\right)$. In these results, it was observed that increasing the degree of substitution of lanthanum increased the formation of secondary phases. The presence of peaks with lower intensities in the formation of strontium oxide for the sample with the lowest degree of substitution $(\mathrm{x}=0.3)$ may be related to the lower strontium concentration when compared to the sample with the highest degree of substitution ( $\mathrm{x}=0.7)$, where the peaks related to the secondary phases were more intense. Studies show that the $\mathrm{NiO}$ phase can be formed together with the perovskite structure [23].

According to the XRD patterns of the LN, L7S3N and L3S7N samples, the formation of $\mathrm{LaNiO}_{3}$ phase in the samples was observed, in which the nickel of the perovskite 


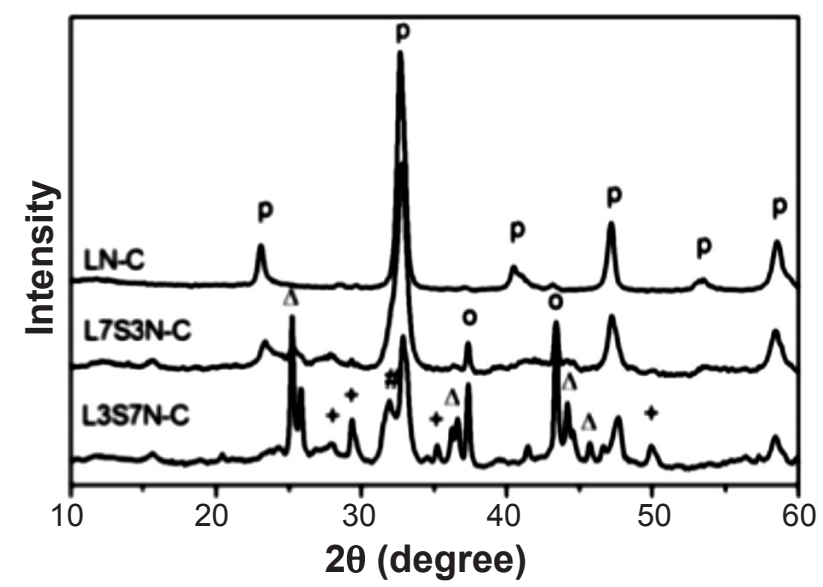

Figure 3: X-ray diffraction patterns for $\mathrm{La}_{1-} \mathrm{Sr}_{\mathrm{x}} \mathrm{NiO}_{3}$ samples calcined at $900{ }^{\circ} \mathrm{C}: \mathrm{p}-\mathrm{LaNiO}_{3} ; \mathrm{o}-\mathrm{NiO} ;+-\mathrm{SrO} ; \Delta-\mathrm{SrCO}_{3}$; and $\#-\mathrm{La}_{2} \mathrm{NiO}_{4}$.

[Figura 3: Difratogramas de raios $\mathrm{X}$ das amostras $\mathrm{La}_{1-x} \mathrm{Sr}_{x} \mathrm{NiO}_{3}$ calcinadas a $900^{\circ} \mathrm{C}$.]

structure is in its $\mathrm{Ni}^{3+}$ oxidation state. However, in the samples in which the lanthanum is partially replaced by strontium (L7S3N and L3S7N samples), in addition to the formation of the perovskite phase, there were mixtures of other phases. The results also indicated that the increase of $\mathrm{Sr}^{2+}$ content (L3S7N sample) favored the formation of the spinel phase $\left(\mathrm{La}_{2} \mathrm{NiO}_{4}\right)$, as observed in the sample L3S7N and by other authors [24]. The strontium accommodation in the structure of lanthanum nickel is more difficult than the same substitution in other similar perovskites [5]. This same observation was related, for example, in solid solutions of $\mathrm{La}-\mathrm{Sr}-\mathrm{Mn}-\mathrm{O}$ without the presence of segregated crystalline phase [7]. However, segregated phases of oxides and carbonates were observed for the compositions with molar amounts of $\mathrm{Sr}^{2+}$ greater than 0.10 and an increase in the oxygen non-stoichiometry with increasing strontium. However, it was observed an increase in the catalytic activity of the catalysts when doped with strontium [5, 7]. Lanthanum $\left(\mathrm{La}^{3+}\right)$ partial substitution by an element of lower charge, in this case strontium $\left(\mathrm{Sr}^{2+}\right)$, changes the stoichiometry of the oxide that is caused by the imbalance of the charges, producing a mixture of the oxidation state of nickel $\left(\mathrm{Ni}^{2+} / \mathrm{Ni}^{3+}\right)$ being compensated by the oxygen deficiency (vacancies) [5], which can generate an improvement in the catalytic activity. The formation of secondary phases may be related to the increase in the degree of imbalance, thus hindering the formation of the perovskite monophasic structure. The diffraction patterns of the samples supported on alumina are shown in Fig. 4. It is observed that the three

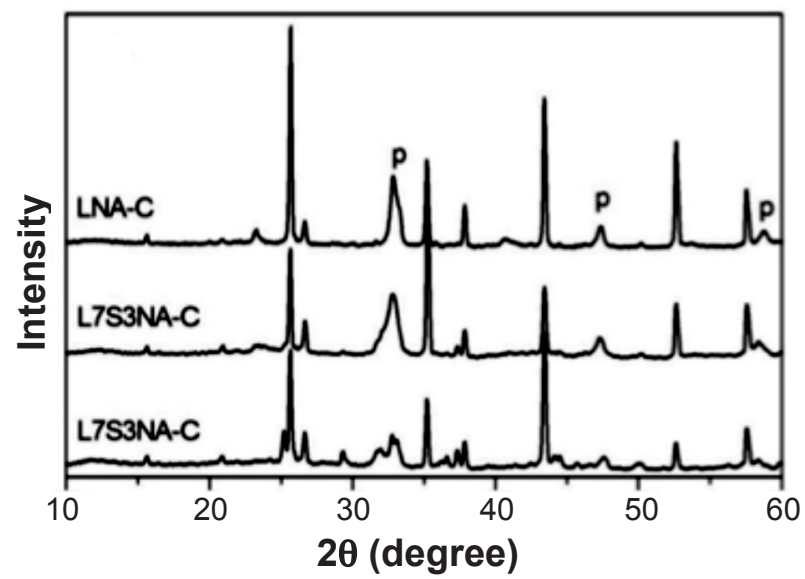

Figure 4: X-ray diffraction patterns for the prepared samples $\mathrm{La}_{1-\mathrm{x}} \mathrm{Sr}_{\mathrm{x}} \mathrm{NiO}_{3} / \mathrm{Al}_{2} \mathrm{O}_{3}: \mathrm{p}$ - perovskite.

[Figura 4: Difratogramas de raios $X$ das amostras $\mathrm{La}_{1-x} \mathrm{Sr}_{x} \mathrm{NiO}_{3} / \mathrm{Al}_{2} \mathrm{O}_{3}$ preparadas: $\mathrm{p}$ - perovskita.]

main characteristic peaks of the perovskites remained, however, with less intensity when compared with peaks of the unsupported samples, in view of the lower content of perovskite on the stand.

Table I shows the specific surface area (SSA) results for samples $\mathrm{La}_{1-x} \mathrm{Sr}_{x} \mathrm{NiO}_{3}$ and $\mathrm{La}_{1-\mathrm{x}} \mathrm{Sr}_{x} \mathrm{NiO}_{3} / \mathrm{Al}_{2} \mathrm{O}_{3}(\mathrm{x}=0.0,0.3$ or 0.7). The results showed surface area values for the $\mathrm{LN}$ materials that were concordant with the expected ( 21 to 38 $\left.\mathrm{m}^{2} \cdot \mathrm{g}^{-1}\right)[6,7]$. It was also possible to observe the effect of the insertion of strontium in the material from the specific surface area values of the prepared catalysts $\mathrm{La}_{1-x} \mathrm{Sr}_{x} \mathrm{NiO}_{3}$ $(x=0.0,0.3$ or 0.7$)$. In general, it was observed that the addition of strontium caused an increase in the values of the specific surface area. This fact can be related to several factors, such as: formation of different crystallites related to different phases present in the material, as well as the substitution of a smaller cation $\left(\mathrm{La}^{3+}=0.106 \mathrm{~nm}\right)$ with a larger cation $\left(\mathrm{Sr}^{2+}=0.113 \mathrm{~nm}\right)$ [7]. These substitutions may result in electronic imbalance depending on the load. The SSA values for the supported samples were increased in relation to the respective unsupported samples. This was probably due to the fact that alumina had a porous structure, which can impart a greater dispersion of the active species on the support and, consequently, result in higher SSA values [9]. In addition, SSA values were the result of support and perovskite contributions.

TPR profiles of the $\mathrm{La}_{1-x} \mathrm{Sr}_{x} \mathrm{NiO}_{3} / \mathrm{Al}_{2} \mathrm{O}_{3}(\mathrm{x}=0.0,0.3$ or 0.7 ) catalysts are shown in Fig. 5. Observing the reduction profile for the LNA catalyst, two reduction peaks were noted:

Table I - Specific surface area (SSA) of the supported $\left(\mathrm{La}_{1-x} \mathrm{Sr}_{x} \mathrm{NiO}_{3} / \mathrm{Al}_{2} \mathrm{O}_{3}\right)$ and unsupported $\left(\mathrm{La}_{1-\mathrm{x}} \mathrm{Sr}_{x} \mathrm{NiO}_{3}\right)$ catalysts.

[Tabela I - Área de superficial específica (SSA) para os catalisadores suportados $\left(\mathrm{La}_{1-x} \mathrm{Sr}_{x} \mathrm{NiO}_{3} / \mathrm{Al}_{2} \mathrm{O}_{3}\right)$ e não suportados $\left(\mathrm{La}_{1-x} \mathrm{Sr}_{x} \mathrm{NiO}_{3}\right)$.]

\begin{tabular}{ccccccc}
\hline Catalyst & LN & L7S3N & L3S7N & LNA & L7S3NA & L3S7NA \\
\hline SSA $\left(\mathrm{m}^{2} \cdot \mathrm{g}^{-1}\right)$ & 21 & 26 & 38 & 47 & 32 & 49 \\
\hline
\end{tabular}


the first at $387{ }^{\circ} \mathrm{C}$ and the second peak at $518{ }^{\circ} \mathrm{C}$. These peaks corresponded to successive changes in the perovskite structure [7]. The first peak referred to the reduction of $\mathrm{Ni}^{3+}$ to $\mathrm{Ni}^{2+}$ from the perovskite structure, corresponding to the formation of $\mathrm{La}_{2} \mathrm{Ni}_{2} \mathrm{O}_{5}$ (Eq. A), and the second peak corresponded to the reduction of $\mathrm{Ni}^{2+}$ to $\mathrm{Ni}^{0}$, with formation of metallic nickel (Eq. B) [15, 25]. In addition, a third peak at $670{ }^{\circ} \mathrm{C}$ was observed for a possible formation of nonstoichiometric nickel aluminate $\left(\mathrm{NiO}-\alpha-\mathrm{Al}_{2} \mathrm{O}_{3}\right)$ [26], due to an interaction between $\mathrm{NiO}$ of the segregated phase with the support alumina (Eq. C):

$$
\begin{aligned}
& 2 \mathrm{LaNiO}_{3(\mathrm{~s})}+\mathrm{H}_{2(\mathrm{~g})} \rightarrow \mathrm{La}_{2} \mathrm{Ni}_{2} \mathrm{O}_{5(\mathrm{~s})}+\mathrm{H}_{2} \mathrm{O}_{(\mathrm{g})} \\
& \mathrm{La}_{2} \mathrm{Ni}_{2} \mathrm{O}_{5(\mathrm{~s})}+2 \mathrm{H}_{2(\mathrm{~g})} \rightarrow \mathrm{La}_{2} \mathrm{O}_{3(\mathrm{~s})}+2 \mathrm{Ni}_{(\mathrm{s})}^{0}+2 \mathrm{H}_{2} \mathrm{O}_{(\mathrm{g})} \\
& \mathrm{NiO}_{(\mathrm{s})}+\mathrm{H}_{2(\mathrm{~g})} \rightarrow \mathrm{Ni}_{(\mathrm{s})}^{0}+\mathrm{H}_{2} \mathrm{O}_{(\mathrm{g})}
\end{aligned}
$$

The partial addition of strontium to the material resulted in significant modifications in the reduction profiles and the appearance of new peaks. These modifications may be indicative of a change in the structural composition of the material. One of the observed changes is in relation to the inversion in the intensities of the first and second peaks in relation to the sample that did not contain strontium. Similar results were reported in [26]. For the samples L7S3NA and L3S7NA, the maxima at 356 and $372{ }^{\circ} \mathrm{C}$ were attributed to several simultaneous steps, such as the reduction of $\mathrm{Ni}^{3+}$ to $\mathrm{Ni}^{2+}$ from the perovskite structure with formation of $\mathrm{La}_{2} \mathrm{Ni}_{2} \mathrm{O}_{5}$ phase (Eq. A). This is then reduced resulting in $\mathrm{Ni}^{0}$ (Eq. B) and reduction of $\mathrm{NiO}$ (due to the secondary phase) in $\mathrm{Ni}^{0}$ (Eq. C). The second peak with maximum at $565^{\circ} \mathrm{C}$ for L7S3NA, and at $417^{\circ} \mathrm{C}$ with an intermediate peak at $388^{\circ} \mathrm{C}$ for L3S7NA, can be attributed to the reduction of $\mathrm{Ni}^{2+}$ to $\mathrm{Ni}^{0}$ for the remaining $\mathrm{NiO}$, suggesting that $\mathrm{Ni}$ metal was not completely reduced between 356 and $372{ }^{\circ} \mathrm{C}$.

The LNA, L7S3NA and L3S7NA catalysts were evaluated on the reaction of partial methane oxidation. The

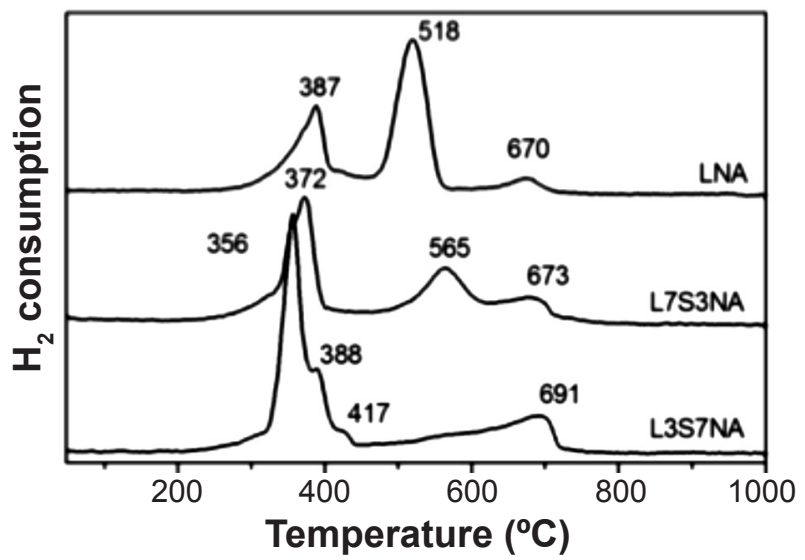

Figure 5: Temperature-programmed reduction profiles for $\mathrm{La}_{1-\mathrm{x}} \mathrm{Sr}_{\mathrm{x}} \mathrm{NiO}_{3} / \mathrm{Al}_{2} \mathrm{O}_{3}$ catalysts.

[Figura 5: Perfis de redução à temperatura programada para os catalisadores $\mathrm{La}_{1-x} \mathrm{Sr}_{x} \mathrm{NiO}_{3} / \mathrm{Al}_{2} \mathrm{O}_{3}$.] catalytic activity of the catalysts was based on methane conversion and the conversion calculation was carried out through the material balance for the carbon, neglecting the coke. In this way, all carbon entering the system in the form of methane must exit as unconverted $\mathrm{CO}_{2}, \mathrm{CO}$ and $\mathrm{CH}_{4}$. Methane conversion and selectivity to $\mathrm{CO}, \mathrm{CO}_{2}, \mathrm{H}_{2}$ and $\mathrm{H}_{2} \mathrm{O}$, as well as $\mathrm{H}_{2} / \mathrm{CO}$ ratio, were analyzed. Conversion and selectivity calculations were performed based on the Eqs. D to $\mathrm{H}$ :

$$
\mathrm{C}(\%)=100 \cdot \frac{\mathrm{C}_{\mathrm{CH} 4}^{0}-\mathrm{C}_{\mathrm{CH} 4}^{\mathrm{f}}}{\mathrm{C}_{\mathrm{CH} 4}^{0}}
$$

where $\mathrm{C}(\%)$ represents methane conversion, $\mathrm{C}_{\mathrm{CH} 4}^{0}$ is the amount of methane matter entering the reactor and $\mathrm{C}_{\mathrm{CH} 4}^{\mathrm{f}}$ is the amount of methane matter in the reactor outlet. All the catalysts evaluated presented selectivity for syngas production. Figs. 6 and 7 show the results of conversion and selectivity. According to the results, it is possible to observe that the LNA sample had a methane conversion of $78 \%$. However, the conversion decreased with increasing strontium content in the samples with conversions of 53 and 38\% for samples L7S3NA and L3S7NA, respectively. The catalysts selectivity to the $\mathrm{CO}$ and $\mathrm{CO}_{2}$ products were calculated by:

$$
\begin{aligned}
& \mathrm{CO}(\%)=100 \cdot \frac{\mathrm{CO}^{\mathrm{f}}}{\mathrm{CO}^{\mathrm{f}}+\mathrm{CO}_{2}^{\mathrm{f}}} \\
& \mathrm{CO}_{2}(\%)=100 \cdot \frac{\mathrm{CO}_{2}^{\mathrm{f}}}{\mathrm{CO}^{\mathrm{f}}+\mathrm{CO}_{2}^{\mathrm{f}}}
\end{aligned}
$$

where $\mathrm{CO}^{\mathrm{f}}$ represents the amount of carbon monoxide matter in the reactor outlet and $\mathrm{CO}_{2}{ }^{\mathrm{f}}$ the amount of carbon dioxide matter in the reactor outlet. The selectivity of the catalysts to the products $\mathrm{H}_{2}$ and $\mathrm{H}_{2} \mathrm{O}$ were calculated through:

$$
\begin{aligned}
& \mathrm{H}_{2}(\%)=100 \cdot \frac{\mathrm{H}_{2}^{\mathrm{f}}}{\mathrm{H}_{2}^{\mathrm{f}} \mathrm{H}_{2} \mathrm{O}^{\mathrm{f}}} \\
& \mathrm{H}_{2} \mathrm{O}(\%)=100 \cdot \frac{\mathrm{H}_{2} \mathrm{O}^{\mathrm{f}}}{\mathrm{H}_{2}^{\mathrm{f}+} \mathrm{H}_{2} \mathrm{O}^{\mathrm{f}}}
\end{aligned}
$$

where $\mathrm{H}_{2}{ }^{\mathrm{f}}$ represents the amount of hydrogen matter in the reactor outlet and $\mathrm{H}_{2} \mathrm{O}^{\mathrm{f}}$ the amount of water matter in the reactor outlet.Fig. 7 shows the selectivity data.It was observed that the catalysts had a low $\mathrm{CO}_{2}$ selectivity, suggesting that they had greater resistance to a possible formation of carbon deposits. The main desirable products are $\mathrm{CO}$ and $\mathrm{H}_{2}$, in a ratio closer to 1:2, which corresponds to the partial oxidation reaction of methane: $\mathrm{CH}_{4}+1 / 2 \mathrm{O}_{2} \rightarrow \mathrm{CO}+2 \mathrm{H}_{2}$ [27]. Among the catalysts, LNA was the most selective to hydrogen, reaching a selectivity value of 55\%, whereas L7S3NA and L3S7NA reached lower values, 46 and 26\%, respectively. In relation to the selectivity to $\mathrm{CO}$ and $\mathrm{CO}_{2}$ (Fig. 7), they evidenced greater selectivity to $\mathrm{CO}$ in relation to $\mathrm{CO}_{2}$, a desirable factor, since the desired product is the synthesis gas. Among the 


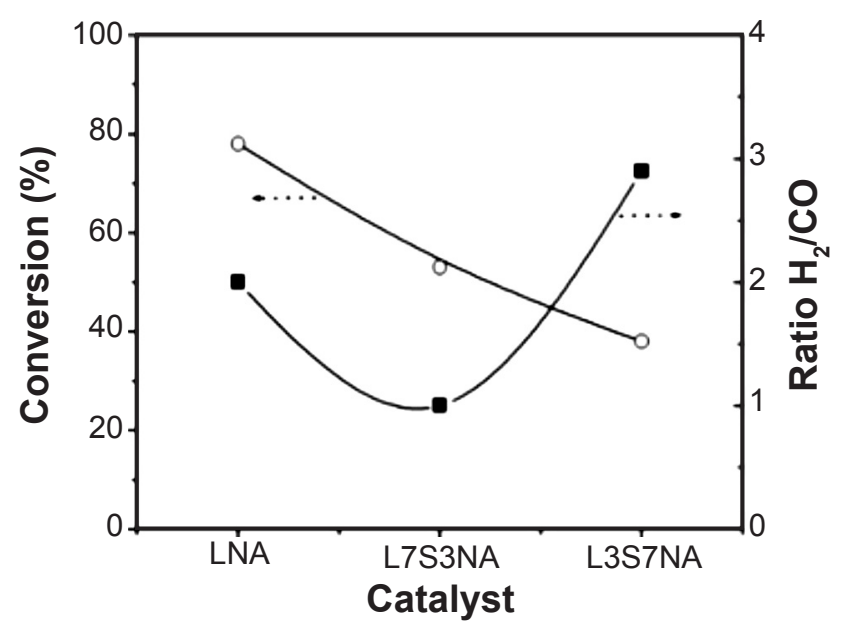

Figure 6: Conversion data and $\mathrm{H}_{2} / \mathrm{CO}$ ratio for LNA, L7S3NA and L3S7NA catalysts.

[Figura 6: Dados de conversão e razão $\mathrm{H}_{2} / C O$ para os catalisadores LNA, L7S3NA e L3S7NA.]

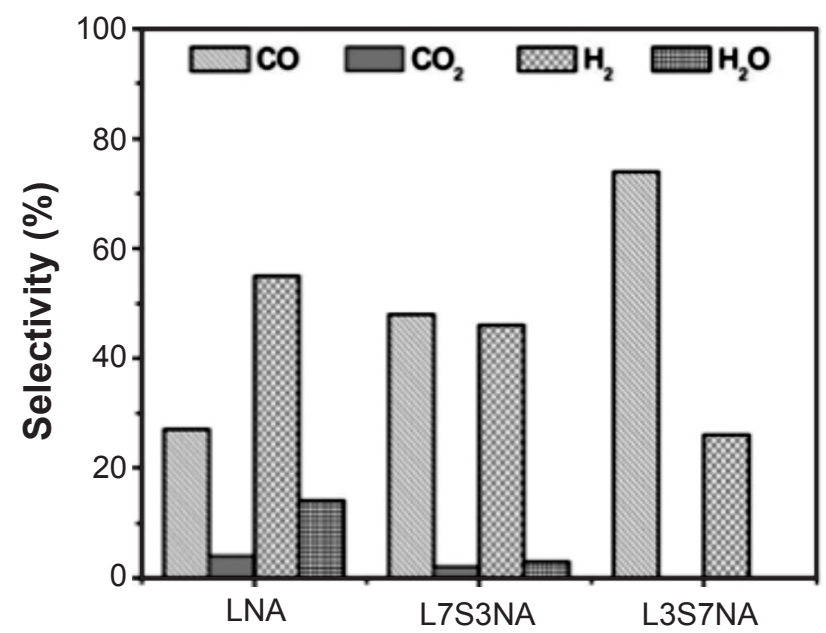

Figure 7: Selectivity to $\mathrm{CO}, \mathrm{CO}_{2}, \mathrm{H}_{2}$ and $\mathrm{H}_{2} \mathrm{O}$ for the catalysts LNA, L7S3NA and L3S7NA.

[Figura 7: Seletividade a $\mathrm{CO}, \mathrm{CO}_{2}, \mathrm{H}_{2}$ e $\mathrm{H}_{2} \mathrm{O}$ para os catalisadores LNA, L7S3NA e L3S7NA.]

catalysts, the most selective to CO was L3S7NA, however, it obtained low selectivity to $\mathrm{H}_{2}$, which makes it undesirable to be an input in the Fischer-Tropsch synthesis reaction. Among the catalysts, the LNA was the most selective to $\mathrm{H}_{2}$ with a value of $55 \%$, while the others reached lower values, mainly L3S7NA with $26 \% \mathrm{H}_{2}$ selectivity. However, L3S7NA was more selective to $\mathrm{CO}$ with a value of $74 \%$. Fig. 6 shows the conversion results of $\mathrm{CH}_{4}$ and $\mathrm{H}_{2} / \mathrm{CO}$ ratio. It was found that the catalysts obtained a decrease in catalytic activity when the lanthanum was partially replaced by strontium. In this case, it was desirable that the activity would increase with the partial replacement of the lanthanum with strontium, a fact that was not verified, suggesting that the formation of segregated materials obtained in samples L7S3NA and L3S7NA could have made difficult the conversion of $\mathrm{CH}_{4}$. In general, the catalyst that obtained the best conversion and a better $\mathrm{H}_{2} / \mathrm{CO}$ ratio of 2 was LNA. It suggested that it has adequate reason to be an input into the Fischer-Tropsch synthesis reaction.

\section{CONCLUSIONS}

The results obtained in this work showed that the use of low cost and non-toxic organic materials such as collagen as a chelating agent in the synthesis of mixed oxides with perovskite structure is promising. According to thermogravimetric curves and absorption spectra in the infrared region, all residual organic material remaining from the synthesis was decomposed to $800{ }^{\circ} \mathrm{C}$, except for samples with $70 \%$ of lanthanum substitution, whose temperature was close to $900{ }^{\circ} \mathrm{C}$. X-ray diffraction patterns for the calcined materials revealed the formation of perovskite in all samples. However, there was the formation of secondary phases with increasing lanthanum substitution content. The perovskite phase was also identified in the supported material $\left(\mathrm{La}_{1-\mathrm{x}} \mathrm{Sr}_{\mathrm{x}} \mathrm{NiO}_{3} / \mathrm{Al}_{2} \mathrm{O}_{3}\right)$ together with the alumina phase. The specific surface area analyses showed that through the synthesis method used values of desirable specific surface area are obtained when compared to other synthesis methods. According to the temperature-programmed reduction profiles, it was observed that the reduction of the materials was favored with the increase in the degree of substitution of the lanthanum. The complete reduction of nickel in the supported samples occurred at a temperature below $700{ }^{\circ} \mathrm{C}$. The catalysts showed catalytic activity in the methane conversion, and the highest conversion level was $78 \%$ for the $\mathrm{LaNiO}_{3} / \mathrm{Al}_{2} \mathrm{O}_{3}$ (LNA) catalyst. For the catalysts $\mathrm{La}_{0.7} \mathrm{Sr}_{0.3} \mathrm{NiO}_{3} / \mathrm{Al}_{2} \mathrm{O}_{3}$ (L7S3NA) and $\mathrm{La}_{0.3} \mathrm{Sr}_{0.7} \mathrm{NiO}_{3} / \mathrm{Al}_{2} \mathrm{O}_{3}$ (L3S7NA), the conversion was 53 and $38 \%$, respectively. The selectivity to $\mathrm{H}_{2}$ was also higher for the LNA catalyst, $55 \%$. The values of ratio of $\mathrm{H}_{2} / \mathrm{CO}$ were $2.0,1.0$ and 2.9 for the catalysts LNA, L7S3NA and L3S7NA, respectively. In general, all the catalysts tested showed satisfactory results in methane conversion. However, the LNA catalyst presented the best result, since the catalysts L7S3NA and L3S7NA showed a decrease in catalytic activity when the lanthanum was partially replaced by strontium.

\section{ACKNOWLEDGEMENTS}

The authors are thankful to CNPq and CAPES for their financial support.

\section{REFERENCES}

[1] M.A. Peña, J.L.G. Fierro, Chem. Rev. 101 (2001) 1981. [2] D. Klvana, J. Vaillancourt, J. Kirchnerova, J. Chaouki, Appl. Catal. 109A (1994) 181.

[3] L.G. Tejuca, J.L.G. Fierro, Properties and applications of perovskites - type oxides, M. Dekker, New York (1993).

[4] L.G. Tejuca, J.L.G. Fierro, J.M.D. Tascon, Adv. Catal. 36 (1989) 237.

[5] R.M Cruz, H. Falcón, M.A. Peña, J.L.G. Fierro, Appl. Catal. B Environ. 33 (2001) 45. 
[6] F.S. Oliveira, P.M. Pimentel, R.M.P.B. Oliveira, D.M.A. Melo, M.A.F. Melo, Mater. Lett. 64 (2010) 2700.

[7] E.Y. Tanabe, E.M. Assaf, Quím. Nova 32 (2009) 1129.

[8] H. Tanaka, M. Misono, Curr. Opin. Solid State Mater. Sci. 5 (2001) 381.

[9] M.C. Álvarez-Galván, V.A. de la Penã O’Shea, G. Arzamendi, B. Pawelec, L.M. Gandía, J.L.G. Fierro, Appl. Catal. B Environ. 92 (2009) 445.

[10] A. Chroneos, R.V. Vovk, I.L. Goulatis, L.I. Goulatis, J. Alloys Comp. 494 (2010) 190.

[11] B.X. Huang, J. Malzbender, R.W. Steinbrech, J. Mater Sci. 46 (2011) 4937.

[12] X. Tong, F. Zhou, S. Yang, S. Zhong, M. Wei, Y. Liu, Ceram. Int. 43 (2017) 10927.

[13] D.S. Melo, E.P. Marinho, L.E.B. Soledade, D.M.A. Melo, S.J.G. Lima, E. Longo, I.M.G. Santos, A.G. Souza, J. Mater. Sci. 43 (2008) 551.

[14] A. Gaki, O. Anagnostaki, D. Kioupis, T. Perraki, D. Gakis, G. Kakali, J. Alloys Compd. 451 (2008) 305.

[15] S.M. Lima, J.M. Assaf, Quím. Nova 30 (2007) 298.

[16] J.C. Santos, M.J.B. Souza, J.A.C. Ruiz, D.M.A. Melo, M.E. Mesquita, A.M.G. Pedrosa, J. Braz. Chem. Soc. 23 (2012) 1858 .

[17] G.R.O. Silva, J.C. Santos, D.M.H. Martinelli, A.M.G. Pedrosa, M.J.B. Souza, D.M.A. Melo, Mat. Sci. Appl. 1
(2010) 39.

[18] K. Nakamoto, Infrared and Raman spectra of inorganic and coordination compounds, John Wiley Sons, New York (1977).

[19] J.C. Santos, M.J.B. Souza, M.E. Mesquita, A.M.G. Pedrosa, Scientia Plena 8 (2012) 3.

[20] F.M. Aquino, D.M.A. Melo, P.M. Pimentel, R.M. Braga, M.A.F. Melo, A.E. Martinelli, A.F. Costa, Mater. Res. Bull. 47 (2012) 2605.

[21] M.R. Nascimento, M.R.C. Santos, S.J.G. Lima, C.D. Pinheiro, J.W.M. Espinosa, E. Longo, A.G Souza, I.M.G. Santos, Cerâmica 54 (2008) 120.

[22] S. Nakayama, M. Okazaki, Y.L. Aung, M. Sakamoto, Solid State Ionics 158 (2003) 133.

[23] C.B. Dupeyrat, G. Valderrama, A. Meneses, F. Martinez, J. Barraul, J.M. Tatibouet, Appl. Catal. A Gen. 143 (2003) 248.

[24] T. Nitadori, M. Muramatso, M. Misono, Bull. Chem. Soc. Jpn. 61 (1988) 3831.

[25] L.D. Vella, J.A. Villoria, S. Specchia, N. Mota, J.L.G. Fierro, V. Specchia, Catal. Today 171 (2011) 84.

[26] T.A. Maia, J.D.A. Bellido, E.M. Assaf, Quim. Nova 3 (2007) 339.

[27] R. Pereñíguez, V.M. González-Delacruz, J.P. Holgado, A. Caballero, Appl. Catal. B Environ. 93 (2010) 346.

(Rec.31/07/2017, Rev. 28/12/2017, Ac. 22/02/2018) 